\title{
MAINTENANCE OF STUDENTS' CODE OF CONDUCT IN DEVELOPING SCHOOL DISCIPLINE
}

\section{${ }^{1}$ Asif khan, ${ }^{2}$ Bibi Asia Naz, ${ }^{3}$ Javed Iqbal, ${ }^{4}$ Riasat Ali, ${ }^{5}$ Zafar khan}

\begin{abstract}
This study was conducted to investigate the students' conduct in developing school discipline at secondary school level. In this research paper, an attempt has been made to investigate the students' conduct as perceived by the principals and class teacher, to compare the views of teacher's position and experience regarding students' conduct and to explore strategies for developing positive conduct amongst the students for secondary school discipline. A descriptive research design was adopted for the study. All the principals of boys' secondary schools and their teachers of secondary classes $\left(9^{\text {th }} \& 10^{\text {th }}\right)$ of District Swabi, Khyber Pakhtunkhwa were the population of the study. Simple random Sampling technique was used for the selection of respondents. From 75 boys secondary schools, 22 principals and 39 teachers having experience more than 10 years responded to a self-developed questionnaire. Data were analyzed through frequency distribution, percentage, mean, standard deviation and t-test. Students' conduct in schools and with their teachers was found below average and a significant difference exists between perceptions of school principals and teachers. Respondents with different experiences have similar views regarding students' code of conduct. A proper code of conduct may be developed and displayed for developing school discipline and teacher should prove himself as a role model for students and psychological techniques should be used.
\end{abstract}

Keywords: Classroom behavior, School discipline, Students' code of conduct

\footnotetext{
${ }^{1}$ Department of Education, Abdul Wali Khan University Mardan

2 Department of Education, Abdul Wali Khan University Mardan

${ }^{3}$ Department of Education, Hazara University

${ }^{4}$ Department of Education, Abdul Wali Khan University Mardan

${ }^{5}$ IER, Gomal University D.I. Khan
} 


\section{Introduction}

According to the new ideologies of education, teaching and education is learner centered. The message is clear in respect that the whole education teaching and learning process evolves round the learner. The responsibilities of an educator became limited in the sense that his every effort should be to change the students' behavior about the learning process. Apart from the role of a quality educator there are other factors which affect the learning environment. These factors are textbook quality, medium of instruction, education quality, school facilities, stimulation, corporal punishment and involvements of parents (Almani, 2007). The practicing area for all of the above factors is school which provides facilitation to apply them practically. If the school environment will be in control and disciplined, the whole process will get through smoothly. As it is stated in Students' Code of Conduct of Orange County Public Schools (2013-2014) that this is the school authority to discipline the students for all those behaviors and acts which are near or correlated to the school. In the sense of discipline, conduct is behavior which can be bad or good. Conduct can be defined as those behaviors which an individual behaves, particularly in a particular place or situation (Oxford Dictionaries Language matters, 2014).

Sometimes kids demonstrate demanding behaviors. When they do not do their homework assigned by their teachers, talking in the class, keep walking around the room, leave the classroom without permission, fight and hit others, spit in the class, throw other learner's objects, hurt others or themselves, then it is said that the student misbehaved (Michigan, Department of Education, 2014). According to Delta School District 37 Administrative Procedures Manual (2013) that it is expected from students that they will adopt acceptable behavior in order to run the school learning activities effectively and avoid the unacceptable which disrupt the learning environment. Students will be held accountable for their behavior if they are disruptive in the school discipline.

The word "Discipline" is always misunderstood and is being taken in negative sense over the last several years, in education in particular. It can be heard from many of them thinking of punishment but in real sense it is not like that. The word "Discipline" is defined by Webster's 1913 
dictionary as both verb and noun to form someone's habits of obedience or to control someone's actions to be systematic (verb) while as noun it is defined as to deal a disciple or learner suitably in order of education by instruction, practice, exercise and training whether it is physically, mentally or morally (webster' 1913 dictionary, 2014). So it means that discipline is not punishment rather it is training and act in order. Thus it gives a clear message that school discipline is for the improvement of students' conduct because discipline is for removal of bad behaviors and substituting the good one (Jackson Public Schools, 2013).

\subsection{Objectives of the Study}

Main objectives of this research study included;

1. To investigate the students' conduct as perceived by the principals and class teacher.

2. To find out differences; position and experience wise of respondents regarding students' conduct.

3. To explore strategies for developing positive conduct amongst the students for secondary school discipline.

\section{Review of Literature}

Research reveals that school discipline paves the way towards the achievement of educational goals. Educational goals consist of students' academic learning, moral and behavioral development. University of Texas at Dallas states in a revise policy (2014) that a student is liable to discipline for his misconduct, prohibited by the university no matter, where ever it occurs on or off campus. The key to success to ensure effective corporate governance is having a code for the concerns. More precisely, code of conduct further strengthens the control over the environment of an organization. As it is stated in an approved "Code of Conduct for Student" by the Department of Education, Republic of South Africa (2008) Act" that the aim of Code of Conduct is to spell out the rules and regulations which concern with the learner's behavior at the School. It further illustrates that the disciplinary system to be put into operation by the school concerning disobedience by learners.

Class discipline is the key to manage a classroom. It is not only provides an environment for learning, facilitates the physical space for students, furniture, wherewithal and stuff, but also provides the 
environment where learners' attitudes and sentiments, and what the society expects of the learning experiences are developed.

Since discipline develops positive behaviors while removes the negative. It reflects the sound that there is no concept that school discipline will be punitive rather it need to constructive. Positive discipline is one which brings the durable change in positive behavior because forcibly applied discipline becomes destructive instead of instructive. As described by Nawaz (2011) that any kind of punishment is always been found as a mercenary in promoting smooth running of activities at school.

Since students know that nothing is happened if they won't go to school, absenteeism, poor academic results and other disciplinary issues raised up. Due to current trend about avoiding corporal punishment lot of disciplinary issues are being faced by teachers inside the class and as well as in the school. It is stated in the The Global Initiative to End All Corporal Punishment of Children (2013) "Right to Free and Compulsory Education Act 2012" which has been passed in Islamabad Capital Territory, and has provided for the right to education for children aged 516 and corporal punishment has been prohibited in government schools for children of the said age which was later on expanded in all provinces of Pakistan. But no alternate choice has been given that how to develop students' positive conduct in order to maintain the school discipline as it has been done in all educationally advanced countries like U.S, U.K, South Africa and Australia etc.

Not only responsibilities of the parents, the students and the school are tackles out by Students' Code of Conduct but also spells out areas connected to; responsibilities and right of learners; ground for disciplinary application and, process to be followed for acts requiring disciplinary action (The School Board of St. Lucie County, 2013).

Hence maintenance of code of conduct for students is the key element in developing progressive discipline of school. Discipline is progressive in the sense that it let students to learn their behavior which they have misbehaved. It does not believe on punishment rather it seeks for the accountability and behavioral change. Here students learn from their own behavior. Discipline becomes progressive when disciplinary actions are applied in a specific process without punishment. In progressive 
discipline, action is taken in a systematic way from less serious to more serious misconduct to be happened (Government of Montana, 2008). Hyman and Perone (1998) commented that victimization of students by teachers, administrators and other school staff, more often in the name of discipline; it is rarely recognized for their potential to contribute misbehavior, student alienation, and aggression.

\subsection{Research Design}

\section{Research Methodology}

The present research was descriptive in nature and a survey was conducted to explore the perceptions of secondary school principals and their teachers about conduct of students.

\subsection{Population and Sample}

The population of the study was secondary Schools of Distt: Swabi Khyber Pakhtunkhwa, province of Pakistan. Out of 75 high school teachers' 38 class teachers whose teaching experience was not less than 10 years were selected through simple random sampling technique.

\subsection{Data Collection and Analysis}

A self-designed questionnaire was distributed personally amongst the principals and teachers. Frequency distribution, percentage, Mean, Standard Deviation, t-test, were used as statistical tools to analyze the collected data.

\section{Results}

Table 1. Students' Conduct as perceived by the principals and class teachers

\begin{tabular}{lccc}
\hline & N & Mean & Std. Deviation \\
Students conduct in schools & 61 & 2.4 & 14.47109 \\
Students conduct in class & 61 & 3.1 & 15.18599 \\
Students conduct with teachers & 61 & 2.3 & 7.02812
\end{tabular}

The average mean (2.5-3.5) has been found out from table 1 of students' conduct according to the perception of the principals and class teachers in the class. Table1 describes the students conduct in school and with teachers $(\mathrm{M} ; 2.4$, S.D; 14.47) and $(\mathrm{M} ; 2.3, \mathrm{SD} ; 7.02)$ respectively and hence is below average. Which shows that students conduct in school and 
with teachers need intensive care and need to be developed through applying some strategies.

Table 2. Comparative views of teachers and principals about students' conduct

\begin{tabular}{llllcccc}
\hline \multicolumn{1}{c}{ Category } & Position & $\mathrm{N}$ & Mean & S.D & $\mathrm{t}$ & $\mathrm{df}$ & $\mathrm{Sig}$ \\
$\begin{array}{l}\text { Students' } \\
\text { conduct in }\end{array}$ & Principals & 22 & 34.3 & 14.91 & .846 & 59 & .980 \\
$\begin{array}{l}\text { School } \\
\text { Students' }\end{array}$ & Principals & 22 & 53.8 & 22.40 & 2.034 & 59 & .000 \\
$\begin{array}{l}\text { conduct in } \\
\text { class }\end{array}$ & Teachers & 39 & 61.8 & 7.92 & & & \\
$\begin{array}{l}\text { Students' } \\
\text { conduct }\end{array}$ & Principals & 22 & 16.1 & 9.30 & 1.485 & 59 & .003 \\
$\begin{array}{l}\text { With } \\
\text { teachers }\end{array}$ & Teachers & 39 & 13.0 & 5.15 & & & \\
\hline
\end{tabular}

Table .2 shows comparative views of teachers and principals about students' conduct. Since $p=0.980>\alpha=0.05$, reveals that there is insignificant differences in the views of teachers and principals about Students' conduct in School while $p=0.000<\alpha=0.05$ and $p=0.003<\alpha$ $=0.05$ exhibit differences significant differences in the opinions of principals and teachers regarding Students' conduct in class and Students' conduct with teachers respectively.

Table 3. Comparative views of respondent's experience regarding students' conduct

\begin{tabular}{|c|c|c|c|c|c|c|}
\hline & & $\begin{array}{l}\text { Sum of } \\
\text { Squares }\end{array}$ & $\overline{d f}$ & $\begin{array}{l}\text { Mean } \\
\text { Square }\end{array}$ & $F$ & Sig. \\
\hline \multirow{4}{*}{$\begin{array}{l}\text { Students conduct in } \\
\text { schools }\end{array}$} & Between & 697.9 & 3 & 232.6 & \multirow{4}{*}{$\begin{array}{r}1.1 \\
17\end{array}$} & \multirow[t]{4}{*}{.350} \\
\hline & Groups & & & & & \\
\hline & Within Groups & 11866.8 & 57 & 208.1 & & \\
\hline & Total & 12564.7 & 60 & & & \\
\hline \multirow{4}{*}{$\begin{array}{l}\text { Students conduct in } \\
\text { class }\end{array}$} & Between & 85.4 & 3 & 28.4 & \multirow{4}{*}{$\begin{array}{r}.11 \\
8\end{array}$} & \multirow[t]{4}{*}{.949} \\
\hline & Groups & & & & & \\
\hline & Within Groups & 13751.4 & 57 & 241.2 & & \\
\hline & Total & 13836.8 & 60 & & & \\
\hline
\end{tabular}




\begin{tabular}{llccrrr}
\hline $\begin{array}{l}\text { Students conduct } \\
\text { with teachers }\end{array}$ & Between & 64.3 & 3 & 21.4 & .42 & .738 \\
& Groups & & & & 1 & \\
& Within Groups & 2899.3 & 57 & 50.8 & & \\
& Total & 2963.6 & 60 & & & \\
\hline
\end{tabular}

Table 3 shows that $\mathrm{F}(3,57)=1.117$ since $\mathrm{p}=0.35>\alpha=0.05, \mathrm{~F}(3$, $57)=0.118$ since $p=0.94>\alpha=0.05$, and $F(3,57)=0.421$ since $p=0$ $.73>\alpha=0.05$, reveals that respondent with different experiences have similar views regarding Students' conduct in schools, Students' conduct in class and Students' conduct with teachers respectively in secondary school's discipline.

Table 4. Suggestions about students' conduct to maintain discipline

\begin{tabular}{llll}
\hline S. No & Suggestions & F $\%$
\end{tabular}

1 Teacher should be a role model himself

7

2 A disciplinary committee should be established

$11 \quad 18.03$

3 Award and reward system should be established

4 Code of conduct for students should developed

5 Psychological techniques( Counseling, Report to

Parents, Corporal Punishment) should be applied

6 Marks of discipline should be placed in examination grading

7 Ethical education should be given

8 Provision of all possible facilities by school in teaching

9 and learning

9 Keeping students busy in creative and learning activities

10 Environment of trust between students and teachers

11 Avoid nepotism ( personal like and dislike)

12 Disciplinary class for students should be arranged once

$19 \quad 31.14$
a week.

The table No. 4 describes that; 
1. $77 \%$ principals and teachers of the selected population agree to apply psychological techniques to reform the students conduct.

2. While ethical education is thought to be effective by $50 \%$ of the respondents.

3. 50.81\% suggests that code of conduct for students need to be developed.

4. $11.47 \%$ gave their views about teachers' to be role model, marks discipline should be specified in certificate awarding and keeping students busy in creative and learning activities.

\section{Discussion}

The students' conduct has an impact on school discipline and teachers' teaching achievements. Importance of students' behavior, inside and outside of class room, cannot be ignored as it affects the overall discipline academically and administratively. Students' class room behavior is important not only for his own academic achievements but also develops confidence in teachers' teaching rather it also affects teachers' personal life. The study found that students' conduct in school and with teachers is below average i.e. the students are not behaving well in the school with peers, other students and teachers. As it is stated in House of Common Education Committee (2011) that the impact on staff, of those pupils, who experience challenging classroom conduct, is enormous. Effects have been cited including constant stress, depression, voice loss, loss of confidence, sickness from teaching resulting in time off work negative impact on home/family life. Poor behavior of students is essential factor in discouraging for entering the teaching profession and has impact upon serving teachers.

Furthermore, many research studies revealed that good conduct of learners is essential for their academic performance while disruptive and bad behavior of students in the class room is caused to reduce their ability to concentration and absorb the information. It was found that students' conduct in class school and with teacher is vital to maintain discipline in class and school. It has been reviewed and validated about twenty three year old statement of the Secretary of State for Education and Science Commission Lord Elton who expressed his concern about some pupils' behavior in certain schools that without good orders it is not possible that 
education will takes place (House of commons Education Committee, 2011).

Although corporal punishment is condemned by majority of the respondents but still it is administered as there is no alternate remedies to resolve the issues. Corporal punishment is still in use in many countries of the world. About 88 countries has legal status and 109 has banned the corporal punishment (Pterson, 2013-14). The study also found the need for formulating some rules and regulations which abide the students to respect the class and school discipline. The principals and teachers views give an idea that only verbal and oral advice is not enough to bring the durable stability in school discipline. There is need of written agreement between the students and schools which can be in the shape of code of conduct for students to strengthen the demands for character building and to maintain the class management and school discipline. Because school code of behavior reflects processes for soothing and reconciliatory dealings (Department of Education and Children's Services, 2007).

For each teacher, safe, secure and free of disruption atmosphere required to impart knowledge to his pupils. It is not possible without consistent and proper adoption and implementation of code of students' conduct which enforce students to cooperate with teachers in class during teaching. Code of students conduct abides students to obey the school discipline policy. Code of students conduct contributes in academic achievements, school success and develops such an environment in the school where learners and school employees feel responsibility and respect to each other (Palm Beach County, 2012).

Findings of the research revealed some strategies which can develop positive behavior in students towards their academic achievements, class and school discipline. But psychological techniques (counseling, report to parents/ collaborate with parents, constructive punishment etc), ethical education and developing a code of conduct for students is effective in maintaining progressive discipline at school. The students should be encouraged to use the courteous language to the teachers and colleagues. They may follow the reasonable direction which is given by the code of conduct of the school. Students should avoid challenging behavior which is considered as contempt of the code. It will be intolerable to assault on 
any of the school staff member. Discrimination, bullying and any kind of harassment towards the staff are equally forbidden. They must not call names, fight and harass other learners, bully, mock about or intentionally harm another student. They must take care of their books and assignments and other related materials, technology, and encourage a climate where learning is cherished (Detroit Public Schools, 2013).

\section{Conclusion}

In the light of the above findings it is concluded that class room teachers' perceive that conduct of students is different in class room as compared to conduct in school. However, the views of school principals' were similar both for conduct in classroom and in school. Experienced teachers have also the same opinions as their principals about students' conduct. Furthermore, both principals and their teachers agreed that psychological techniques should be applied to reform students' conduct by focusing on ethical education and allocation of certain marks to discipline.

\section{Recommendations}

The principals and the most experienced class teachers recommended maintaining discipline in class and schooling that;

1. Effort may be made to use psychological techniques i.e. Counseling, Report to Parents, Corporal Punishment in order to develop positive behavior in students towards their teachers, class and school discipline.

2. A proper code of conduct for students may be developed and displayed on notice board for developing school discipline.

3. Seminar, conference on ethical education need to be arranged for students in and outside the school.

4. Proper policies for award and reward system need to be improved and displayed in the school.

5. Disciplinary classes for students should be arranged at least once a week in the school.

6. Staff should avoid nepotism and an environment of trust between the students and teachers may be developed.

7. Teacher should prove himself as a role model for students. 


\section{References}

Almani, A. S., \& Abro, A. D. (2007-08). Attitide of people towards education: A case study of Matyari and Hyderabad District. The SU journal of Education, 37.

Administrative Procedures Manual. (2013, May). Student Conduct and Discipline. Delta School District 37 Inspired Learning, BC, Canada.

Code of Student Conduct. (2013). Code of Student Conduct. Florida: The School Board of St. Lucie County.

Department of Education and Children's Services. (2007). School Discipline. North South Wales Department of Eduction Australia.

Department of Education Republic of south Africa. (2008). Google search engine. In E. Departement, Example of Code of Conduct for a School. Pretoria: Formeset Digital, Tshwane

Detroit Public Schools. (2013). Students'Rights, Responsibilities \& Code of Conduct. Michigan, USA.

Government of Montana. (2008). Dicipline Handline Guide-State Human Resource Division. Retrieved 3 1, 14, from hr.mt.gov/content/hrpp/docs/Guides/Disciplineguide08.pdf

House of commons Education Committee. (2011). Behaviour and Discipline in Schools. London: House of Commons London: The Stationary Office Limited.

Hyman, I. A., \& Perone, D. C. (1998). The other side of school violence: Educator policies and practices that may contribute to student misbehavior. Journal of School Psychology, 36(1), 7-27.

Jackson Public Schools. (2013). 2013-14 Code of Student Conduct. Mississippi. 
Michigan, Department of Education. (2014, April 3). Alternatives to Corporal punishment. Michigan, U.S. Retrieved 2014, from www.michigan.gov.

Nawaz, D. A. (2011). The Impact of Corporal Punishment on Students' Academic Performance/Career and Personality Development Upto Secondry Level Education in Khyber Pakhtoonkhwa Pakistan. International Journal of Business and Social Science, 130-140.

Orange County Public Schools. (2013-14). Code of Conduct of students Orange County Public Schools. Florida: Orange County Public Schools Florida.

Oxford Dicsionaries Language matters. (2014). Retrieved March 28, 2014, from www.oxforddictionaries.com:http://www.oxforddictionaries.com/d efinition/american_english/conduct

Pterson, T. (2013-14). Eliminating teachers use of corporal punishment in Jordon. USA: Univercity of Harward.

Palm Beach County. (2015-16). Student Code of Conduct (Elementary). Florida, USA: The School District of Palm Beach County.

The Global Initiative to End All Corporal Punishment of Children. (2013). Summary of necessary legal reform to achieve full prohibition. Islamabad: prepared by the Global Initiative to End All Corporal Punishment of Children.

University of Texas. (2014). Students Code of Conduct. Dallas: University of Texax at Dallas Retrieved from http://policy.utdallas.edu/utdsp5003

webster' 1913 dictionary. (2014). Retrieved June 2014, from ywww.Google.com.pk: dictionary.org/definition/Discipline http://www.webster- 